\title{
The determination of tryptophan in purified proteins and in feeding-stuffs
}

\author{
By N. A. MATHESON \\ Rowett Research Institute, Bucksburn, Aberdeen $A B z{ }_{9} S B$
}

(Received 22 August 1973-Accepted 26 November 1973)

\begin{abstract}
I. A method was developed for the estimation of tryptophan in purified proteins or in feeding-stuffs. Samples were hydrolysed by autoclaving them with barium hydroxide in polypropylene flasks or tubes. Excess $\mathrm{Ba}$ was precipitated as the hydroxide by cooling, and hydrogen sulphide formed during hydrolysis was removed under reduced pressure. Tryptophan was assayed colorimetrically with dimethylaminobenzaldehyde by comparison with tryptophan standards carried through the complete procedure.

2. The method was applied to purified proteins, to analysed materials and to a wide range of samples. Results agreed fairly well with published values for purified proteins, though rather less well for the samples analysed by other workers. Reasons are discussed. The samples examined gave results in the expected range.
\end{abstract}

Tryptophan, unlike most other amino acids, is generally unstable to acid hydrolysis, especially if carbohydrate is present during the hydrolysis. Spies \& Chambers (I949) avoided such destruction by using proteins which were still intact, since bound tryptophan as well as free tryptophan produced colour in their method. Unfortunately, the colour yields of free and of bound tryptophan were different (Shaw \& McFarlane, r940; Evered, 1961). Spies (1967) later developed a method which overcame this problem but it also required prior hydrolysis of the sample. The destruction of tryptophan during acid hydrolysis has appeared to be an insuperable difficulty in the use of this procedure in analysis, but recently protection with thioglycollic acid during hydrochloric acid hydrolysis (Matsubara \& Sasaki, 1969) and hydrolysis with $p$ toluenesulphonic acid (Liu \& Chang, I 97I) have both been found to give large yields of tryptophan. These methods are interesting but still too novel to be adequately assessed. Enzymic hydrolysis seemed too slow and often inapplicable to feeding-stuffs. Alkaline hydrolysis was the most obvious method left. Hydrolysis with sodium hydroxide tends to be slower than that with barium hydroxide (Warner, 1942) and sodium may be more difficult to remove than barium but some workers have found this method satisfactory (Spies, 1967; Oelshlegel, Schroeder \& Stahmann, I970; Hugli \& Moore, 1972). Ba is easily precipitated as the carbonate or sulphate, but, unfortunately, these compounds tend to carry down some tryptophan with them (Miller, I967; Robel, 1967). Nevertheless hydrolysis with barium hydroxide was the method of choice in the past, and more recently several workers have used it (Miller, 1967; Slump \& Schreuder, I969; Knox, Kohler, Palter \& Walker, I970).

In the work reported below, a brief account of which has already been given (Matheson, I973), barium hydroxide hydrolysis was used and losses of tryptophan were avoided or taken into account. After development, the method was applied to samples of purified protein and to feeding-stuffs. 


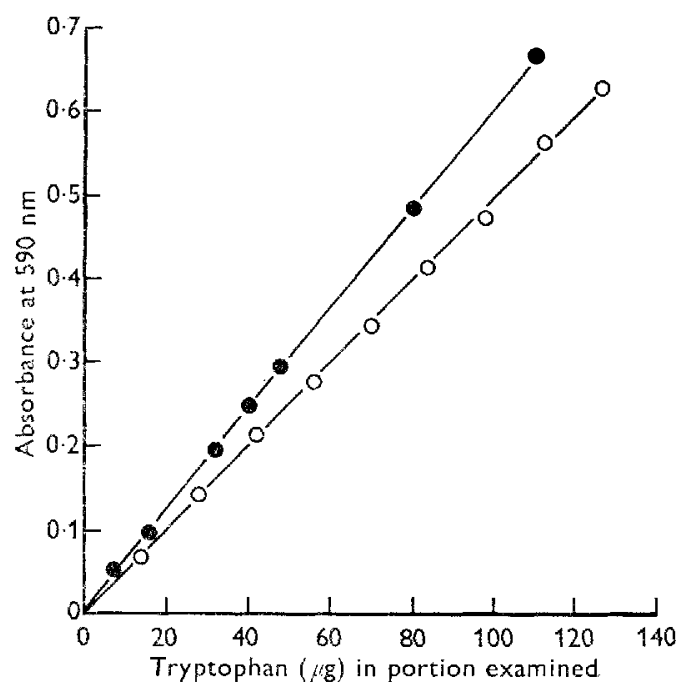

Fig. 1. Tryptophan determination in the presence and the absence of barium. The system contained various amounts of tryptophan in either $2 \mathrm{ml}$ water or $2 \mathrm{ml}$ saturated $\mathrm{Ba}$ (OH), solution and $5 \mathrm{ml}$ of a solution of $5 \mathrm{~g} \mathrm{4}$-dimethylaminobenzaldehyde $119 \mathrm{M}-\mathrm{H}_{2} \mathrm{SO}_{4}$. Conditions were otherwise as detailed on p. 395 in the recommended procedure. $\mathrm{O}$, with $\mathrm{Ba}$; , no Ba.

\section{EXPERIMENTAI.}

\section{Materials}

$L$-tryptophan, bovine pancreas insulin (crystalline), bovine haemoglobin (crystalline, type I), egg albumin and $\alpha$-chymotrypsinogen (type II) were supplied by Sigma (London) Chemical Co. Ltd, Surrey. Crystallized bovine plasma albumin was supplied by Armour Pharmaceutical Co., Eastbourne, $\beta$-lactoglobulin by Pentex, Inc., Kankakee, Illinois 609r, USA, and soluble starch (Analar), glucose (Analar) and 4-dimethylaminobenzaldehyde (Analar) by British Drug Houses, Poole, Dorset; $\beta$-casein was prepared by W. B. Watt (Rowett Research Institute, Aberdeen).

The samples of feeding-stuffs were supplied by $\operatorname{Dr} \mathrm{A}$. A. Woodham (Rowett Research Institute, Aberdeen) from the materials used by the Protein Evaluation Group of the Agricultural Research Council (ARC). Samples of other materials for analysis were supplied by Dr V. R. Fowler (Rowett Research Institute, Aberdeen).

\section{Analytical method for tryptophan}

4-Dimethylaminobenzaldehyde (DMAB) reacts with tryptophan (reaction I) and the product, when treated with sodium nitrite, gives a blue colour (reaction 2). Under appropriate conditions the intensity of the colour is proportional to the amount of tryptophan present. These reactions were studied; it was shown that reaction I was slower than reaction 2 , but that both reactions appeared to be complete within $60-90$ min. The DMAB was dissolved in either concentrated hydrochloric acid (Miller, 1967) or strong sulphuric acid (Spies \& Chambers, 1949). It was found that when the reagent prepared in sulphuric acid was used the response to tryptophan was rectilinear, 
Table I. Effect of starch, glucose or sucrose on tryptophan assay

(A mixture of $5.2 \mathrm{mg}$ tryptophan and $500 \mathrm{mg}$ of the carbohydrate shown were put through the complete macro-procedure for tryptophan analyses, including autoclaving and dilution (10o-fold))

\begin{tabular}{lcc} 
& \multicolumn{2}{c}{$\begin{array}{c}\text { Tryptophan in } \\
\text { portion examined }\end{array}$} \\
\cline { 2 - 3 } & $\begin{array}{c}\text { Found } \\
(\mu \mathrm{g})\end{array}$ & $\begin{array}{c}\text { Recovered } \\
(\%)\end{array}$ \\
Sample & 52 & 100 \\
Tryptophan & 46 & 88 \\
Tryptophan + starch & 50 & 96 \\
Tryptophan + glucose & 46 & 88 \\
Tryptophan + sucrose & 4
\end{tabular}

but with hydrochloric acid there was a curvilinear response. Examination of the absorption spectrum of the reaction mixture confirmed that there was a maximum at $590 \mathrm{~nm}$.

Hydrolysis with barium hydroxide was studied. Tryptophan gave a blue colour with DMAB ( $\left.5 \mathrm{~g} / 19 \mathrm{M}_{\mathrm{I}}-\mathrm{H}_{2} \mathrm{SO}_{4}\right)$; when the tryptophan was dissolved in barium hydroxide solution this colour was still about $80 \%$ of that in the absence of barium hydroxide (Fig. I). Autoclaving the sample in an open polypropylene flask was as effective as hydrolysis in sealed evacuated glass tubes, judged by recovery of tryptophan from natural materials (fish meal, wheat middlings). The presence of sulphur in many samples results in the production of hydrogen sulphide which was found to interfere with the colour development. If the hydrolysate was subjected to reduced pressure in a desiccator containing a lead acetate solution this interference was avoided. It was found that varying the length of the hydrolysis period from 8 to $24 \mathrm{~h}$ had little effect on the recovery of tryptophan; that tryptophan, in the presence of a barium hydroxide solution at $0^{\circ}$, was stable for at least $8 \mathrm{~d}$; and that precipitation of $\mathrm{Ba}$ as the carbonate by absorption of $\mathrm{CO}_{2}$ resulted in no loss of tryptophan, as judged by subsequent colour development, provided that the carbonate precipitate was not removed from the reaction mixture.

Studies of interference by compounds likely to be present in foods and feedingstuffs showed that the presence of excess starch, glucose or sucrose all lessened the recovery of pure tryptophan (Table I). For example, a $12 \%$ lowering in colour yield occurred when $5.2 \mathrm{mg}$ tryptophan and $500 \mathrm{mg}$ starch - a ratio of about $\mathrm{I}: 100-$ were autoclaved together and then carried through the complete procedure. It was found that inhibition by starch occurred even without autoclaving.

Recommended procedure. On the basis of the above findings two methods for determination were devised, one being a micro-adaptation of the other. In the macromethod, material (as a solid ground to pass a sieve of $400 \mu \mathrm{m}$ mesh, as a solution or as a pipettable suspension) containing $\mathrm{I}-\mathrm{IO} \mathrm{mg}$ tryptophan, ${ }_{5} 5.8 \mathrm{~g} \mathrm{Ba}(\mathrm{OH})_{2} \cdot 8 \mathrm{H}_{2} \mathrm{O}$ and water to a total volume of $9 \mathrm{ml}$, ignoring the volumes of all solids, are put in polypropylene flasks. These are loosely covered and placed in a preheated autoclave; then the pressure inside is increased so that the temperature rises to $115^{\circ}$, the air being vented for 5 min periods when the temperature is at $100^{\circ}$, $108^{\circ}$ and $115^{\circ}$. 
Table 2. Tryptophan content of purified protein

\begin{tabular}{|c|c|c|c|c|}
\hline & & \multicolumn{2}{|c|}{$\begin{array}{l}\text { Tryptophan content } \\
\text { (mgig dry wt) }\end{array}$} & \multirow[b]{2}{*}{ Reference } \\
\hline Material & Source & Found & $\begin{array}{l}\text { Literature } \\
\text { value }\end{array}$ & \\
\hline $\begin{array}{l}\text { Bovine pancreas } \\
\text { insulin }\end{array}$ & Sigma & $\circ$ & $\circ$ & Harfeinest (1953) \\
\hline Bovine serum albumin & Sigma & $5 \cdot 0$ & $5 \cdot 7$ & Spahr \& Edsall (rg64) \\
\hline Bovine $\beta$-casein A & W. B. Watt & $8 \cdot 0$ & $8 \cdot 2$ & MeKenzie $(1967)$ \\
\hline Hen-egg albumin & Sigma & 10.9 & $12 \cdot 0$ & Gottschalk \& Bruce-Graham (I 966) \\
\hline $\begin{array}{l}\text { Bovine haemoglobu- } \\
\text { lin }\end{array}$ & Sigma & 14.7 & $18 \cdot 9$ & Kitchen (1969) \\
\hline $\begin{array}{l}\text { Bovine } \beta \\
\text { lactoglobulin }\end{array}$ & Pentex & $24 \cdot I$ & $22 \cdot 7$ & McKenzie ( 1967$)$ \\
\hline $\begin{array}{l}\text { Bovine pancreas } \\
\alpha \text {-chymotrypsinogen } \mathrm{A}\end{array}$ & Sigma & $52 \cdot 4$ & $57 \cdot 1$ & Wilcox, Cohen \& Tan (1957) \\
\hline
\end{tabular}

These flasks are kept at $115^{\circ}$ for $\mathrm{I} 6 \mathrm{~h}$, then removed, and the hot contents are made up to $100 \mathrm{ml}$ with water. These are stored at $0^{\circ}$ overnight, when much barium hydroxide crystallizes out and settles along with any insoluble matter. A known volume of supernatant liquid and of sulphuric acid (usually $5 \mathrm{ml}$ supernatant liquid and $0.1 \mathrm{ml}$ $9 \mathrm{M}$-sulphuric acid in this laboratory) are placed in a vacuum desiccator containing a saturated lead acetate solution and no desiccant. Pressure is lowered as far as possible without spurting. The odour of hydrogen sulphide should no longer be detectable in about $4 \mathrm{~h}$ when the next stage of analysis may be carried out. A slight loss in weight from the acidified hydrolysates occurs during removal of hydrogen sulphide, but it may be measured and allowed for in subsequent calculations. Portions of the wellmixed suspensions from the hydrolysates are made to $2 \mathrm{ml}$ with barium hydroxide solution saturated at $o^{\circ}$ and then gently shaken with $5 \mathrm{ml}$ of $5 \mathrm{~g} \mathrm{DMAB} / 19 \mathrm{M}-\mathrm{H}_{2} \mathrm{SO}_{4}$. The mixtures are left in the dark for $45 \mathrm{~min}$ at room temperature and then $0.2 \mathrm{ml}$ sodium nitrite $(2 \mathrm{~g} / 1)$ is added to each and mixed; the suspensions are centrifuged for $20 \mathrm{~min}$ at $1500 \mathrm{~g}$ and the absorbances of the clear supernatant fractions are read at $590 \mathrm{~nm}$ about $90 \mathrm{~min}$ after the beginning of the estimation. A reagent blank with no tryptophan and a sample blank in $9 \mathrm{M}-\mathrm{H}_{2} \mathrm{SO}_{4}$ without DMAB are also included in each batch.

From a curve produced from standards it was found that:

Net absorbance $\times 200=$ tryptophan content $(\mu \mathrm{g})$ of portions examined.

When the method is applied to less abundant materials such as purified proteins a micro-modification is used. The weights of sample and barium hydroxide and the initial and final volumes of the system are $O .1$ of that in the macro-method, and the hydrolysis is carried out in polypropylene tubes. The rest of the determination is as in the macro-method.

\section{Application}

The method was applied to several purified proteins whose tryptophan contents were available in the literature (Table 2 ). 


\section{Table 3. Recovery of tryptophan added to a feeding-stuff}

(The tryptophan content of a feeding-stuff was determined alone and after the addition of a known amount of tryptophan. The additional tryptophan added before hydrolysis is equivalent to $56 \mu \mathrm{g}$ in the portion assayed colorimetrically)

\begin{tabular}{|c|c|c|c|}
\hline \multirow[b]{2}{*}{ Sample alone* } & \multirow{2}{*}{$\begin{array}{l}\text { Samplet } \\
\text { tryptophan* }\end{array}$} & \multicolumn{2}{|c|}{ Recovery of added tryptophan } \\
\hline & & $\mu \mathrm{g}$ & $\%$ \\
\hline $5 I \cdot 8$ & 103.9 & $52 \cdot I$ & 93 \\
\hline $35^{-8}$ & 92.5 & $56 \cdot 7$ & IOI \\
\hline $64 \cdot 8$ & I $19 \cdot 3$ & $54 \cdot 5$ & 97 \\
\hline $79^{\circ}$ & $\mathbf{I}_{3} \mathbf{2} \cdot 8$ & $53 \cdot 8$ & 96 \\
\hline 37.0 & $92 \cdot 4$ & $55^{\circ} 4$ & 99 \\
\hline $28 \cdot 5$ & $85^{\circ} 0$ & $56 \cdot 5$ & IOI \\
\hline
\end{tabular}

Fish meal FMior

Fish meal FMro2

Fish meal FMi22

Hydrocarbon yeast HYIOI

Meat meal Mior

Sunflower-seed meal SFior

(four determinations per sample) whose standard error is $\pm \mathrm{I} \cdot 8 \%$.

Table 4. Tryptophan content of feeding-stuffs determined by various methods

\begin{tabular}{|c|c|c|c|c|c|c|}
\hline \multicolumn{2}{|c|}{ Sample } & \multicolumn{5}{|c|}{ Tryptophan content [mg/g crude protein $(\mathrm{N} \times 6 \cdot 25)]$} \\
\hline Material & No. & NAM* & ARC Anal† & ARC Biolt & $\mathrm{C} \& \mathrm{E} \$$ & $\mathrm{~F} \& \mathrm{~S} \|$ \\
\hline \multirow[t]{5}{*}{ Fish meal } & FMror & $9 \cdot 4$ & II*I & $6 \cdot 8$ & $6 \cdot 3$ & $6 \cdot 5$ \\
\hline & FMro2 & $8 \cdot 3$ & $9 \cdot 5$ & $4 \cdot 8$ & $6 \cdot 2$ & 5.6 \\
\hline & FMI08 & $12 \cdot 6$ & $14 \cdot 2$ & $9^{\cdot} \cdot \mathbf{I}$ & 一 & $12 \cdot 9$ \\
\hline & FMI22 & II $\cdot 5$ & I $3 \cdot 5$ & I I $\cdot 0$ & - & I 0.8 \\
\hline & FMI23 & $12 \cdot 4$ & 14.0 & I $2 \cdot 0$ & - & II' 3 \\
\hline \multirow[t]{2}{*}{ Hydrocarbon yeast } & HYror & $\mathrm{I} 3 \cdot 4$ & $\mathrm{r} 2 \cdot 2$ & $12 \cdot 0$ & - & I 6 \\
\hline & $\mathrm{HYxO}_{4}$ & $14 \%$ & $12 \cdot 2$ & $12 \cdot 0$ & - & $\operatorname{Ir} 3$ \\
\hline Meat meal & MMror & $8 \cdot 7$ & 10.5 & $4 \cdot 5$ & 5.5 & $7 \cdot 4$ \\
\hline Groundnut meal & GNIOI & I $2 \cdot 0$ & I $3 \cdot I$ & $8 \cdot 0$ & $8 \cdot 5$ & II 8 \\
\hline Soya-bean meal & SBror & 14.7 & I $4 \cdot 5$ & 14.0 & - & I $3 \cdot 0$ \\
\hline Sunflower-seed & SFIOI & I 37 & I $3 \cdot 6$ & I 4.0 & - & $\mathrm{r} 3 \cdot 2$ \\
\hline
\end{tabular}

meal

* Colorimetric procedure described on p. 395; mean of four replicates (two determinations on each of two hydrolysates), converted from $\mathrm{mg} / \mathrm{g}$ basis using $\mathrm{N}$ analysis.

$\dagger$ Colorimetric procedure by ARC Analytical Panel (K. J. Carpenter \& A. A. Woodham, in preparation).

I Chick assay method by ARC Biological Panel (K. J. Carpenter \& A. A. Woodham, in preparation). Strictly, this method gives tryptophan available to chicks rather than total tryptophan but these are likely to be close in good-quality feeding-stuffs.

$\S$ Ion-exchange chromatography by Nadeem Chaudry \& Evans (I97 I).

II Microbiological assay by J. E. Ford \& K. J. Scott (preliminary results in a personal communication).

The tryptophan contents of feeding-stuffs with and without added tryptophan were measured. The recoveries of tryptophan are given in Table 3. A number of feedingstuffs used by the Protein Evaluation Group of the ARC were analysed for tryptophan by the macro-procedure described here (Table 4 ). The results were compared with those of several other workers who analysed the same material.

Tryptophan was estimated by the recommended macro-method in a range of samples being analysed routinely at this Institute for other purposes (Table 5). 
Table 5. Tryptophan content, estimated by the macro-procedure (see p. 395), of a wide range of materials being examined at this station

(Two hydrolysates ( $A$ and $B$ ) were madc from every sample, and the tryptophan content of each was determined on two portions of different sizes; mean results for each hydrolysate are given)

\begin{tabular}{|c|c|c|c|c|c|c|}
\hline \multirow{3}{*}{ Material } & \multirow[b]{3}{*}{$\begin{array}{l}\text { Nitrogen } \\
\text { content } \\
(\mathrm{mg} / \mathrm{g})\end{array}$} & \multirow[b]{3}{*}{$\begin{array}{c}\text { Dry-matter } \\
\text { content } \\
\text { (mg/g) }\end{array}$} & \multirow[b]{3}{*}{$\begin{array}{l}\text { Hydro- } \\
\text { lysate } \\
\text { used }\end{array}$} & \multicolumn{3}{|c|}{ Tryptophan content } \\
\hline & & & & & & \\
\hline & & & & $\begin{array}{l}\text { Mean for } \\
\text { hydrolysate }\end{array}$ & $\begin{array}{l}\text { Mean for } \\
\text { sample }\end{array}$ & $\begin{array}{c}\mathrm{mg} / \mathrm{g} \text { protein } \\
(\mathrm{N} \times 6.25)\end{array}$ \\
\hline Pig muscle (FD) & $128 \cdot 5$ & $93^{\circ}$ & $\begin{array}{l}A \\
B\end{array}$ & $\begin{array}{l}9 \cdot 5 \\
9 \cdot 3\end{array}$ & $9 \cdot 4$ & I I 7 \\
\hline Pig carcass (FD) & $5 \mathrm{I} \cdot 7$ & 967 & $\begin{array}{l}A \\
B\end{array}$ & $\begin{array}{l}3 \cdot 1 \\
3 \cdot 2\end{array}$ & $3 \cdot 2$ & $9 \cdot 9$ \\
\hline Pig offal (FD) & $2 I \cdot 6$ & 983 & $\begin{array}{l}A \\
B\end{array}$ & $\begin{array}{l}I \cdot 2 \\
I \cdot I\end{array}$ & $\mathrm{I} \cdot 2$ & $8 \cdot 9$ \\
\hline Fatty tissue of pig (FD) & - & 940 & $\begin{array}{l}A \\
B\end{array}$ & $\begin{array}{l}0.36 \\
0 \cdot 35\end{array}$ & $0 \cdot 3^{6}$ & - \\
\hline Grass (GD) & $24 \cdot 8$ & $93^{\circ}$ & $\begin{array}{l}A \\
B\end{array}$ & $\begin{array}{l}2 \cdot 6 \\
2 \cdot 3\end{array}$ & $2 \cdot 5$ & $I 6 \cdot I$ \\
\hline $\begin{array}{l}\text { Protein from rumen } \\
\text { bacteria (FD) }\end{array}$ & $82 \cdot 5$ & 880 & $\begin{array}{l}A \\
B\end{array}$ & $\begin{array}{l}5 \cdot 7 \\
5 \cdot 6\end{array}$ & $5 \cdot 7$ & I I 0 \\
\hline Skim-milk powder & $58 \cdot I$ & 959 & $\begin{array}{l}A \\
B\end{array}$ & $\begin{array}{l}4 \cdot 6 \\
4 \cdot 6\end{array}$ & $4 \cdot 6$ & $12 \cdot 7$ \\
\hline Pig diet & $3 x \cdot 3$ & 884 & $\begin{array}{l}A \\
B\end{array}$ & $\begin{array}{l}2 \cdot 0 \\
2 \cdot 0\end{array}$ & $2^{\prime} 0$ & 10.2 \\
\hline Barley & I6'I & 884 & $\begin{array}{l}A \\
B\end{array}$ & $\begin{array}{l}I \cdot 2 \\
I \cdot 2\end{array}$ & $\mathrm{I} \cdot 2$ & I I 9 \\
\hline Turnips (FD) & I $2 \cdot 8$ & 838 & $\begin{array}{l}A \\
B\end{array}$ & $\begin{array}{l}0.77 \\
0.7 x\end{array}$ & 0.74 & $9 \cdot 2$ \\
\hline Soya beans (ground) & $80 \cdot 1$ & 909 & $\begin{array}{l}A \\
B\end{array}$ & $\begin{array}{l}6 \cdot 2 \\
6 \cdot 7\end{array}$ & $6 \cdot 5$ & 13.0 \\
\hline
\end{tabular}

FD, freeze-dried; GD, dried in a hot-air grass dricr; pig carcass, whole carcass less head, offal, skin and some dissectible fat.

\section{RESULTS AND DISCUSSION}

Chloride ions have been reported to interfere in tryptophan assay with DMAB (Lesuk, I948), and Spies (1950) has shown how to avoid such interference. Presumably the non-rectilinear response with the reagent prepared in hydrochloric acid was due to interference by chloride ions. The reagent prepared with sulphuric acid, however, gave a rectilinear response to tryptophan and so was chosen for the method described.

The speed of the reactions used in tryptophan assay is such that the over-all reaction rate could only be limited by reaction $\mathrm{I}$. The use of a suitable development time allows all reactions to be virtually complete and so avoids the need to time tubes individually.

Ba was shown to inhibit the reactions used to estimate tryptophan with DMAB, but under fixed conditions the degree of inhibition was constant. Tryptophan could be determined in the presence of a low concentration of $\mathrm{Ba}$ provided the standards 
were determined in similar conditions and no precipitates were discarded except where noted. It proved possible to remove most of the Ba from a hydrolysate as barium hydroxide, which is comparatively insoluble at $\mathrm{o}^{\circ}$, and this method was convenient in practice.

Hydrolysis before analysis seems necessary for heterogeneous samples, and alkaline hydrolysis with barium hydroxide appeared most suitable. The need for a large number of analyses in applied studies and in some fundamental research means many hydrolyses in the absence of oxygen and carbon dioxide and could be met by autoclaving the samples with barium hydroxide, and since hot alkaline solutions tend to dissolve glass the hydrolyses were done in polypropylene vessels (Miller, I967; Oelshlegel et al. I970). Hydrolysis of proteinaceous material with barium hydroxide produces hydrogen sulphide, which interferes with the reactions of DMAB used to estimate tryptophan, but may be removed by bubbling nitrogen through the hydrolysates or, more conveniently, by keeping the hydrolysates at a low pressure in the presence of lead acetate solution. Added hydrogen sulphide lowers the apparent tryptophan concentration of a solution of the amino acid, but its removal restores the level to its former value. The effect seems to be on the chemical reactions used to determine tryptophan rather than on the amino acid itself.

Starch, glucose and sucrose were found to interfere in tryptophan estimation, but again the effect appears to be due to the action of these compounds on the reactions used to determine tryptophan, and no prior autoclaving of inhibitor and sample is needed to show the effect. Table 3 shows that in a series of protein concentrates, including sunflower meal which contains appreciable carbohydrate, and hydrocarbon yeast which contains complex polysaccharide, recovery of added tryptophan was satisfactory, suggesting that for materials of a similar nature interference from carbohydrate is not a serious consideration.

The macro-procedure applied to samples used by the Protein Evaluation Group of the ARC gave results in rough agreement with those of the Group and other workers. The values obtained by the method described here are in better agreement with the preliminary results found by J. E. Ford and K. J. Scott's (personal communication) microbiological technique than any other. Since no set of results obtained by any method consistently agrees closely with any other set, exact agreement of the new method and any one set of values cannot be expected.

The tryptophan contents of a wide range of samples were determined (Table 5). The results seem reasonable and were reproducible; the main difficulty was that of obtaining a representative sample. No problems were encountered in putting any of the samples through the procedure. However, since the recovery of tryptophan was found to be reduced in the presence of excess starch, it may be that further work will show that appropriate amounts of starch should be added to the standards when the method is used for the analyses of cereals and other starchy materials.

It is surprising that a single method gave accurate results on proteins and reproducible results on feeding-stuffs and physiological materials. Tryptophan, previously a difficult amino acid to determine, is so easy to assay by the method described above that it may be used as a marker in studies with proteins. 
I thank Mr A. W. Moir for his technical assistance in this work, Dr J.W. G. Porter (National Institute for Research in Dairying, Reading) for permission to quote the results of ARC Panels before publication, and Dr K. J. Carpenter (School of Agriculture, Cambridge) and Dr A. A. Woodham (Rowett Research Institute, Aberdeen) for supplying these results; Dr J. E. Ford (National Institute for Research in Dairying, Reading) for allowing me to quote his analyses before publication, Dr A. A. Woodham for suggesting work on tryptophan estimation and for supplying samples of material used by the Protein Evaluation Group of the ARC, $\mathrm{Mr}$ W. B. Watt (Rowett Research Institute, Aberdeen) for a gift of $\beta$-casein and Dr V. R. Fowler (Rowett Research Institute, Aberdeen) for samples of various biological materials for tryptophan assay.

\section{REFERENCES}

Evered, D. F. (196I). Analyt. Biochem. 2, 280.

Gottschalk, A. \& Bruce-Graham, E. R. (1966). In The Proteins Vol. 4, and ed., p. 95 [H. Neurath, editor]. New York and Iondon: Academic Press.

Harfeinest, E. J. (1953). F. Am. chem. Soc. 75, $55^{28}$.

Hugli, T. E. \& Moore, S. (1972). \%. biol. Chem. 247, 2828.

Kitchen, H. (r969). Adv. vet. Sci. comp. Med. 13, 247.

Knox, R., Kohler, G. O., Palter, R. \& Walker, H. G. (1970). Analyt. Biochem. 36, I36.

Lesuk, A. (1948). Report on Collaborative Study on Chemical Tests and Standard for Amino acids, Letter 135. Washington, DC: US Pharmacopocia Amino Acids Advisory Committee.

Liu, T.-Y. \& Chang, Y. H. (r97x). F. biol. Chem. 246, 2842.

McKenzie, H. A. (1967). Adv. Protein Chem. 22, 55.

Matheson, N. A. (1973). Proc. Nutr. Soc. 32, 98 A.

Matsubara, H. \& Sasaki, R. H. (1969). Biochem. biophys. Res. Commun. 35, 175.

Miller, E. L. (1967). F. Sci. Fd Agric. 18, 38 I.

Nadeem Chaudry, M. T. \& Evans, R. A. (I97 I). Proc. Nutr. Soc. 30, 69 A.

Oelshlegel, F. J. Jr, Schroeder, J. R. \& Stahmann, M. A. (r 970). Analyt. Biochem. 34, 33 r.

Robel, E. J. (1967). Analyt. Biochem. 18, 406.

Shaw, J. L. D. \& McFarlane, W. D. (1940). F. biol. Chem. 132, 387.

Slump, P. \& Schreuder, H. A. W. (1969). Analyt. Biochem. 27, 182.

Spahr, P. F. \& Edsall, J. T. (I964). F. biol. Chem. 239, 850.

Spies, J. R. (1950). Analyi. Chem. 22, 1447.

Spies, J. R. (1967). Analyt. Chem. 39, I412.

Spies, J. R. \& Chambers, D. C. (1949). Analyt. Chem. 21, 249.

Warner, R. C. (1942). F. biol. Chem. 142, 74I.

Wilcox, P. E., Cohen, E. \& Tan, W. (r957). F. biol. Chem. 228, 999. 